\title{
ОСОБЛИВОСТІ ОРГАНІЗАЦІЇ ОБЛІКУ РОЗРАХУНКІВ З БІЗНЕС-ПАРТНЕРАМИ ЩОДО ЕКОЛОГІЧНОЇ ДІЯЛЬНОСТІ ЛІСОГОСПОДАРСЬКОГО ПІДПРИЕМСТВА
}

\begin{abstract}
Необхідною умовою екологічно сталого, екозбалансованого функціонування підприємств лісового комплексу є відповідність між взаємозв'язаними його структурними елементами - раціональне використання та відтворення лісових ресурсів. Це завдання має вирішувати лісогосподарський менеджмент. У сучасному менеджменті щоразу чіткіше проявляється значення системних знань про значення лісових ресурсів, що дають змогу не тільки своєчасно і якісно управляти поточним лісокористуванням, але й прогнозувати розвиток подій у лісоресурсній сфері, зокрема в соціально-екологічному аспекті. УПравління лісоекологічною діяльністю доцільно проводити з використанням системного підходу, оскільки дослідження взаємодії лісогосподарювання, навколишнього середовища та населення визначає умови, які могли б сприяти сталому лісокористуванню. Облік розрахунків із постачальниками та підрядниками є найважливішою ділянкою бухгалтерської роботи, оскільки на цьому етапі формується основна частина доходів та грошових надходжень підприємств. Поглиблення сутніснозмістовної основи екологізації управління з позиції функціонального, системного, ситуаційного та процесного підходів $є$ необхідною умовою подальшого розвитку економічних механізмів та методів екологічного менеджменту в контексті принципів сталого багатоцільового лісокористування та екосистемного управління лісами. Розглянуто особливості організації обліку розрахунків 3 партнерами по бізнесу щодо екологічної діяльності лісогосподарського підприємства. Оцінено потенціал існуючих розробок щодо організації обліку розрахунків із партнерами по бізнесу підприємств. Розроблено прикладні пропозиції щодо розрахунків лісогосподарського підприємства 3 партнерами по екологічній діяльності. Запропоновано організацію обліку розрахунків лісогосподарського підприємства щодо його екологічної діяльності з постачальниками, підрядниками, замовниками.
\end{abstract}

Ключові слова: лісові ресурси; система управління; постачальники і підрядники; екоменеджмент; план рахунків.

Вступ. Питанням теоретико-методологічних і практичних аспектів щодо обліку розрахунків із постачальниками приділяли увагу такі вітчизняні вчені: Ф. Ф. Бутинець (Butynets \& Kotsupatryi, 2003), М. Ф. Огійчук (Ohiychuk, 2001), Н. М. Ткаченко (Tkachenko, 2008), C. В. Баран (Baran, 2004), але питання обліку розрахунків 3 партнерами по бізнесу щодо екологічної діяльності підприємств в їх роботах не розглянуто. Це і зумовлює необхідне проведення спеціального дослідження організації обліку розрахунків з партнерами по бізнесу щодо екологічної діяльності лісогосподарського підприємства. При цьому треба врахувати існуючі розробки теоретико-методологічних засад формування системи екологічного управління та екоменеджменту підприємств, зокрема в лісовому господарстві.

Значний внесок у розвиток теоретико-методологічних засад функціонування системи екологічного управління та екоменеджменту зробили О. Ф. Балацький, О. О. Веклич, Т. П. Галушкіна, Б. М. Данилишин, С. І. Лебедевич, В. О. Лук'янихін, Ю. Ю. Туниця, Є. В. Хлобистов, В. Я. Шевчук та ін.
Предметом дослідження є організація обліку розрахунків з партнерами по бізнесу щодо екологічної діяльності лісогосподарського підприємства.

Основними завданнями $є$ :

1) аналізування існуючих розробок з організації обліку розрахунків підприємств 3 партнерами по бізнесу щодо можливості їх використання стосовно організації обліку екологічної діяльності підприємств;

2) розроблення пропозицій з організації обліку розрахунків з партнерами по бізнесу щодо екологічної діяльності лісогосподарського підприємства.

Викладення основного матеріалу дослідження. Зростання інтересу з боку суспільства і держави до збереження і покращення якості навколишнього середовища та охорони здоров'я людини організації дедалі частіше приділяють увагу потенційно можливого впливу своєї діяльності, продукції або послуг на навколишнє природне середовище. Екологічні характеристики функціонування організації набувають щоразу більшого значення для внутрішніх і зовнішніх зацікавлених сторін (Andrusiak, 2013, p. 7).

\section{Інформація про авторів:}

Лебедевич Світлана Іванівна, д-р екон. наук, професор, кафедра обліку і аудиту. Email: lebedevych.sv@gmail.com Вихопень Орися Андіївна, магістрант, кафедра обліку і аудиту. Email: Orysya24@ukr.net

Цитування за ДСтУ: Лебедевич С. І., Вихопень О. А. Особливості організації обліку розрахунків з бізнес-партнерами щодо екологічної діяльності лісогосподарського підприємства. Науковий вісник НлтУ України. Серія Економічна. 2018, т. 28 , № 9. C. $54-56$

Citation APA: Lebedevych, S. I., \& Vykhopen, O. A. (2018). Features of accounting organization based on business partners with regard to the ecological activity of forestry enterprise. Scientific Bulletin of UNFU, 28(9), 54-56. https://doi.org/10.15421/40280910 
Система обліку - це основна інформаційна система підприємства. Ї̈̈ використовують для формування звітів, контролю, оцінки, а також під час вибору політики підприємства та прийняття рішень у нестандартних ситуаціях (Hornhret \& Foster, 2000, p. 8). Важливими питаннями системи управління на підприємстві $є$ раціональний вибір партнерів щодо постачання необхідних обсягів запасів та оптимізація розрахунків за них і їхніх облік (Hachaturov, et al., 2000). Для оптимального вибору постачальників критеріями можуть бути різноманітні чинники. Практична діяльність лісогосподарських підприємств свідчить, що головними чинниками під час вибору постачальників залишаються ціна, складовою якої $є$ транспортні витрати; умови, на яких закуповуються запаси, враховуючи: оптимальну їх доставку та витрати на транспортування, вид транспорту та оптимальний маршрут доставки (Pohribna \& MatvieievaAleksieieva, 2013).

Порядок і форми розрахунків із постачальниками визначаються господарськими договорами, внаслідок виконання яких у підприємства виникають поточні зобов'язання - кредиторська заборгованість. Облік розрахунків 3 постачальниками та підрядниками $\epsilon$ найважливішою ділянкою бухгалтерської роботи, оскільки на цьому етапі формується основна частина доходів та грошових надходжень підприємств. Розрахунки - це операції, з одного боку, спрямовані на забезпечення підприємства сировиною, матеріалами, паливом, тарою, а 3 іншого - реалізація готової продукції (Shylova \& Moskalyk, 2018).

Необхідною умовою екологічно сталого, екозбалансованого функціонування підприємств лісового комплексу $\epsilon$ відповідність між взаємозв'язаними його структурними елементами - раціональне використання та відтворення лісових ресурсів. Це завдання має вирішувати лісогосподарський менеджмент. Поняття і сутність менеджменту постійно змінюються відповідно до етапів розвитку суспільного виробництва (зокрема лісогосподарського), набуваючи нових рис та особливостей (Iarova, 2018). Виникнення, формування і розвиток системи екологічного менеджменту $є$ не лише соціально, але й методологічно обгрунтованим. Екологічний менеджмент не $\epsilon$ деякою надбудовою або відгалуженням сучасної науки про управління, це логічний розвиток концепції всеосяжного менеджменту якості, основа філософії сучасного менеджменту, що існує на сьогодні (Насhaturov, et al., 2000).

Управління лісоекологічною діяльністю доцільно проводити з використанням системного підходу, оскільки дослідження взаємодії лісогосподарювання, навколишнього середовища та населення визначає умови, які могли б сприяти сталому лісокористуванню. При цьому системний підхід до якісного застосування методів дає змогу провести дослідження об'єкта з позицій закономірності системного цілого і взаємодії складових його параметрів (Shylova \& Moskalyk, 2018). Вирішення еколого-економічних проблем природогосподарювання у лісовому комплексі потребує розроблення комплексного механізму екологічного менеджменту. Ефективне його функціонування потребує системи управління еко- лого-економічними знаннями (Iarova, 2018). Отже, існуючі розробки в організації обліку розрахунків підприємства з партнерами по бізнесу варто здійснювати, використовуючи систему еколого-економічного управління на базі еколого-бухгалтерського обліку.

Пропонуємо організацію обліку розрахунків лісогосподарського підприємства щодо його екологічної діяльності з постачальниками, підрядниками, замовниками здійснювати в рамках існуючої системи організації обліку підприємств. При цьому потрібно використовувати існуюче технічне забезпечення, адаптоване до застосування аналітичного екологічного обліку. Організаційне забезпечення обліку варто доповнити, зокрема треба внести зміни щодо специфіки екологічної діяльності в положення про бухгалтерію підприємства, в посадові інструкції бухгалтерів розрахункового відділу. Інформаційне забезпечення організації обліку потрібно доповнити чинним природоохоронним законодавством та наявними методичними рекомендаціями науковців щодо організації еколого-бухгалтерського обліку.

Висновки. Отже, у спеціальному дослідженні, яке ми провели, оцінено потенціал існуючих розробок щодо організації обліку розрахунків із партнерами по бізнесу підприємств та теоретико-методологічних основ еколого-економічного менеджменту з метою використання в організації обліку екологічної діяльності лісогосподарського підприємства. Розроблено прикладні пропозиції щодо впровадження в існуючу облікову систему еколого-бухгалтерського обліку розрахунків лісогосподарського підприємства 3 партнерами по екологічній діяльності.

\section{Перелік використаних джерел}

Andrusiak, N. S. (2013). Ekolohichnyi menedzhment i audit. Chernivtsi: RODOVID, 195 p. [In Ukrainian].

Baran, S. V. (2004). Stvorennia systemy pidtrymky pryiniattia rishen na osnovi ekonomiko-matematychnoyi modeli vyboru postachalnykiv resursiv dlia hirnyco-vydobuvnyh pidpryiemstv. (Vol. 4). Ekonomika: problem teorii ta praktyky, 193(4), 1307-1316. [In Ukrainian].

Butynets, F. F., \& Kotsupatryi, M. M. (2003). Bukhhalterskyi oblik u silskomu hospodarstvi. Zhytomyr: PP "Ruta", 512 p. [In Ukrainian].

Hachaturov, A. E., Huseva, T. V., Kretov, I. I., \& Panin, T. S. (2000). Ekolohichnyi marketynh. Marketynh v Rosii i za mezhamy, 4.

Hornhret, Ch. T., \& Foster, Dzh. (2000). Bukhhalterskyi oblik: upravlinskyi aspect. Kyiv: Vychtcha shkola, 416 p. [In Ukrainian].

Iarova, I. Ie. (2018). Orhanizatsiyno-ekonomichni zasady ekolohizatsii upravlinnia lisovym hospodarstvom. Retrieved from: https://essuir.sumdu.edu.ua/bitstream/123456789/8856/1/14.pdf. [In Ukrainian].

Ohiychuk, M. F. (2001). Bukhhalterskyi oblik na silskohospodarskyh pidpryiemstvah. Kyiv: Ahrarna osvita, 605 p. [In Ukrainian].

Pohribna, O. P., \& Matvieieva-Aleksieieva, V. V. (2013). Udoskonalennia obliku rozrahunkiv z postacchalnykamy zapasiv na ahropromyslovyh pidpryiemstvah. Retrieved from: http://www.znptdau_2013_1_3 27.pdf. [In Ukrainian].

Shylova, T. S., \& Moskalyk, A. V. (2018). Problemy obliku rozrahunkiv z postachalnykamy ta pidriadnykamy. Problemy formuvannia novoi ekonomiky XXI stolittia: Materialy IV Mizhnarodna naukovopraktychna konferentsia, (pp. 23-28). Retrieved from: http://www.confcontact.com/20111222/8 shilova.php. [In Ukrainian].

Tkachenko, N. M. (2008). Bukhhalterskyi finansovyi oblik, opodatkuvannia $i$ zvitnist. (3rd ed.). Kyiv: Alerta, 926 p. [In Ukrainian]. 


\title{
ОСОБЕННОСТИ ОРГАНИЗАЦИИ УЧЕТА РАСЧЕТОВ С БИЗНЕС-ПАРТНЕРАМИ ОТНОСИТЕЛЬНО ЭКОЛОГИЧЕСКОЙ ДЕЯТЕЛЬНОСТИ ЛЕСОХОЗЯЙСТВЕННЫХ ПРЕДПРИЯТИЙ
}

Необходимым условием экологически устойчивого, экосбалансированного функционирования предприятий лесного комплекса является соответствие между взаимосвязанными его структурными элементами - рациональное использование и воспроизводство лесных ресурсов. Эту задачу должен решать лесохозяйственный менеджмент. В современном менеджменте все четче проявляется значение системных знаний о значении лесных ресурсов, позволяющих не только своевременно и качественно управлять текущим лесопользованием, но и прогнозировать развитие событий в лесоресурсной сфере, в частности, в социально-экологическом аспекте. Управление лесоэкологической деятельностью целесообразно проводить с использованием системного подхода, поскольку исследования взаимодействия лесохозяйствования, окружающей среды и населения определяет условия, которые могли бы способствовать устойчивому лесопользованию. Учет расчетов с поставщиками и подрядчиками является важным участком бухгалтерской работы, поскольку на этом этапе формируется основная часть доходов и денежных поступлений предприятий. Углубление сущностно-содержательной основы экологизации управления с позиции функционального, системного, ситуационного и процессного подходов является необходимым условием дальнейшего развития экономических механизмов и методов экологического менеджмента в контексте принципов устойчивого многоцелевого лесопользования и экосистемного управления лесами. Рассмотрены особенности организации учета расчетов с партнерами по бизнесу по экологической деятельности лесохозяйственного предприятия. Оценен потенциал существующих разработок по организации учета расчетов с партнерами по бизнесу предприятий. Разработаны прикладные предложения по расчетам лесохозяйственного предприятия с партнерами по экологической деятельности. Предложена организация учета расчетов лесохозяйственного предприятия по его экологической деятельности с поставщиками, подрядчиками, заказчиками.

Ключевые слова: лесные ресурсы; система управления; поставщики и подрядчики; экоменеджмент; план счетов.

\author{
S. I. Lebedevych, O. A. Vykhopen \\ Ukrainian National Forestry University, Lviv, Ukraine
}

\section{FEATURES OF ACCOUNTING ORGANIZATION BASED ON BUSINESS PARTNERS WITH REGARD TO THE ECOLOGICAL ACTIVITY OF FORESTRY ENTERPRISE}

A prerequisite for the environmentally sustainable, ecologically balanced operation of forestry enterprises is the correspondence between their interconnected structural elements - rational use and reproduction of forest resources. Forest management should deal with this task. The concept and essence of management are constantly changing in accordance with the stages of the development of social production, in particular, forestry, acquiring new features. In modern management, the importance of systematic knowledge about the necessity of forest resources, which allows both managing current forest use timely and qualitatively, and also predicting the development of events in the forest resource sector, in particular, in the socio-ecological aspect, is more clearly revealed. It is expedient to conduct the management of the forestry activities using a systematic approach, since research on the interaction of forest management, the environment and the population determines the conditions that could contribute to sustainable forest management. Accounting for payments with suppliers and contractors is the most important part of accounting work, since at this stage the bulk of income and cash receipts of enterprises is formed. The deepening of the substantive basis of ecologization of management from the point of view of functional, systemic, situational, and process approaches is a prerequisite for the further development of economic mechanisms and ecological management methods in the context of the principles of sustainable multi-purpose forest management and ecosystem forest management. The peculiarities of accounting of settlements with business partners concerning ecological activity of forestry enterprise are considered. The potential of existing developments in the organization of accounting of settlements with business partners of enterprises is estimated. Applied proposals for calculations of a forest enterprise with partners on ecological activity are developed. Forming of accounting of forestry enterprise calculations concerning its environmental activity with suppliers, contractors, and customers is offered.

Keywords: forest resources; control system; suppliers and contractors; ecological management; account plan. 